\title{
Emilie Ruch
}

\section{'Metatheatre and Dramaturgical Innovation: A Study of Recognition Scenes in Euripides' Tragedies Electra, Helen, Iphigenia in Tauris, and Ion'}

\section{Introduction}

By associating the concepts of metatheatre and dramaturgical innovation, I aim to demonstrate how the study of metatheatre is indivisible from the study of dramaturgy, to which it belongs. Indeed, if we follow Roland Barthes' definition of meta-literature ${ }^{1}$ as 'literature which takes itself as its object', then I deduce from the very composition of the term (with the meta-prefix followed by a common name) that metatheatre is a generic sub-category that comprises a discourse that refers to its theatrical nature.

It seems important to me to distinguish first and foremost the two concepts of metapoetry ${ }^{2}$ and metatheatre, which in my opinion cannot be used interchangeably: even though both concepts refer to the fictional nature of the associated work, speaking of metatheatre is more precise and refers to the generic properties of the theatrical work. Therefore, metatheatre is a form of speech that refers to the scenic representation - the performance - which summons the audience's hearing and sight. Yet these generic qualities of theatre are also those which fall under the scope of dramaturgical study. ${ }^{3}$ The metatheatrical remarks that I will comment upon throughout this chapter will therefore highlight

\section{Barthes (2002) 364-365.}

2 I think in particular of the work of I. Torrance, who studied metapoetry in the Euripidean corpus. See Torrance $(2011 ; 2013)$.

3 Dramaturgical study consists mainly in the study of three topics: the work of the author (the play's structure, the characters' composition and the poetry), the play's performance (the use of props, the staging in its visual and aural dimensions) and the audience's reception (the study of the expectations caused by tradition or genre, the classification of the different levels of reception, the innovations of the playwright). See Taplin (1978), Wiles (1987) and Pavis (1980) s.v. 'dramaturgie’ 135-138 and s.v. ‘dramaturgique’ (analyse) 139-140.

Notes: I would like to thank again the editors of this volume for giving me the opportunity to present here my work. 
the characteristics of Euripidean dramaturgy as it is implemented in four of his tragedies: Electra, Helen, Iphigenia in Tauris and Ion.

If I have restricted my corpus to Euripides' tragedies of recognition, it is because, in my opinion, these works especially allow us to understand the expression of the poet's aesthetic choices. Importantly, Euripides took a special interest in recognition at the end of his career. In the agonistic context of theatrical creation in the $5^{\text {th }}$ century $\mathrm{BC}$, to treat the topical scene of the recognition amounts to including oneself in a line of authors and theatrical representations in order to measure oneself against them and to try and surpass them. To sum up, a topos that is both literary and theatrical is therefore also based on conventions and expectations inherent in the pattern. Spectators, for example, had to wait for certain key steps of the recognition, such as the identification by one of the two characters involved, the speech as a mean of persuasion, the expression of disbelief, doubt or mistrust from one of the protagonists, the claim or proving one's identity, the memory of past suffering, and finally, the expression of joy and the embrace. ${ }^{4}$ In particular, we can think of the case of Euripides' Electra, whose close relationship with Aeschylus' Libation Bearers has been remarked upon many times. ${ }^{5}$ This example clearly illustrates how Euripides not only consciously entered into a relationship of literary filiation with his predecessor, but also how he exploited this heritage to emphasize the originality of his own production. To the latter point, it is much easier to show the novelty of a process when it is contextualized by codes and within a tradition belonging to the common cultural substratum. Moreover, if one thinks of the tragedies' production context in annual drama competitions, it is not an exaggeration to assume that at least some of the audience took pleasure in identifying similarities and differences between recognition scenes. ${ }^{6}$ The fact that Euripides chose to follow such a pattern, especially one repeated several times in a short period of time, represents, in my opinion, an active reflection on the conditions of theatrical creation at that time.

While it is important to understand the context of Euripides' actions, the repeated treatment of recognition in the last pieces of the Euripidean corpus was not only a convenient means for the author to surpass his opponents. Indeed, Euripides' metatheatrical practice would be relatively poor if it merely explained and claimed its originality. After all, the very principle of innovation is extremely

4 Furthermore, it is important to have in mind that each of these steps involves a specific vocabulary and codified stage games. These vocabulary and stage games will be commented upon throughout this paper.

5 See for example: Aélion (1983); Bond (1974); Conacher (1967) 199-212; Noël (2013); Roux (1974) 42-56; Torrance (2011); Torrance (2013) 14-33.

6 For the audience's pleasure, see also Di Virgilio and Duncan in this volume. 
limited in its duration, always exposing itself to the inventiveness of a successor. Importantly, however, Euripides' metathetrical practice suggests especially that this practice allowed the playwright to express the singularity of his theatrical choices through the exploration of the same pattern. Thus, what Euripides sought to represent in these scenes is not only the difficulty posed to the characters (at the level of the plot) to achieve the recognition, but also (for the poet), onstage and in front of a large audience, the brief and imperceptible move from ignorance to knowledge. ${ }^{7}$ Consequently, the many metatheatrical remarks inserted into Euripidean recognition scenes are not only references to the reality of the poetic composition and the fictional character of the tragic work, but they are also, above all, indications of a serious interrogation by the playwright of the conventions that surround the topical scene. ${ }^{8}$

When considered in more detail, Euripides' metatheatrical remarks clearly illustrate the characteristics of theatrical performance and its livelihood. In his remarks, the costumes, the accessories, the surprising changes of context, and even the senses awoken during the theatrical performance are mentioned. Therefore, by drawing the public's attention to the process and the scenic tools used during the performance, Euripides was able to give his viewers a glimpse of the behind-the-scenes and to help improve their understanding of the show. Metatheatre became a theatrical reading and teaching tool that gave the viewer the keys to access the various degrees of meaning of the tragic work. ${ }^{9}$

To demonstrate that metatheatre was consciously used by Euripides to report the new and original aesthetic that he built into his recognition scenes, I will proceed in three stages. I will first show that his metatheatrical remarks are a sign that Euripides was questioning the validity of the traditional codes of the recognition scene. Secondly, I will demonstrate that Euripides did not adopt a

7 The level of the plot and the level of the dramatic construction are not opposed here, but work together as equal components of the play. In fact, the concept of metatheatre solves the problems raised by the question of the direct address to the public and the rupture of the dramatic illusion: we can say that there is no such thing as the rupture of the dramatic illusion precisely because the metatheatre makes it possible to bring into existence two levels of concomitant discourse that do not destroy each other, that is to say the level of the plot and the level of the metatheatrical comment. See Marshall (2000). In contrast, see Bain's point of view: Bain (1987).

8 See Arnott, G. (1973) about Euripides' conscious game with conventions.

9 The concept of metatheatre also allows us better to account for the diversity of the Athenian public and its skills, literary or theatrical, but also the variables induced by the particular reception within $\theta \varepsilon \dot{\alpha} \alpha \rho o v$ (sight, hearing, attention or concentration, interruptions, theatrical experience or not, etc.). See Cole, T. (1997); Cole, S. (2008) and Revermann (2006). On the audience's competence, see also Di Virgilio in this volume. 
purely reflexive and critical attitude, but that he endeavoured to create new tools for staging the recognition. Finally, I will defend the idea that the many metatheatrical remarks that Euripides inserted into his tragedies were not only descriptive, but also allowed him to promote a new dramaturgical model to his audience.

\section{Metatheatre as a Tool for Questioning the Recognition Scene's Conventions}

I will first examine several examples of recognition scenes. Together, these indicate that Euripides was questioning the proper theatrical means to stage the process of recognition. Recognition (a complex cognitive process) occurs when theoretical knowledge is combined with sensory perception such as hearing and especially sight. Euripides sought to represent this cognitive process in a concrete way by rendering it audible and visible onstage. It was not only a matter of confronting a scene already treated by his predecessors; the playwright also had to make this as clear as possible through its staging.

For a clear example, witness the famous scene of Electra (below). Rather than repeating the familiar elements that would merely reflect the resumption of Libation Bearers, I instead draw attention to the structure of the passage and to the vocabulary used by the two characters at the misunderstanding that pits Electra against the old servant just before the recognition. ${ }^{10}$

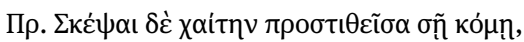

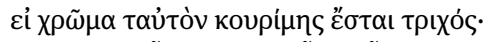

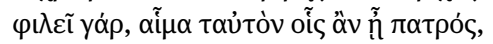

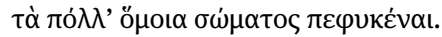

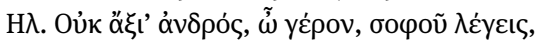

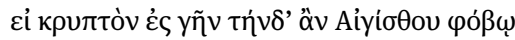

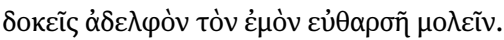

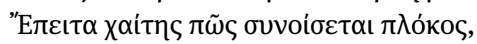

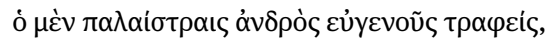

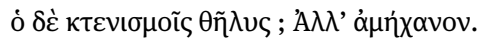

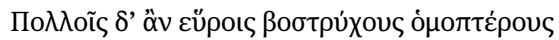

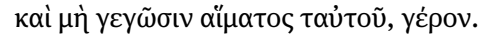

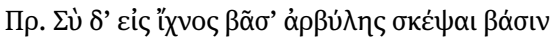

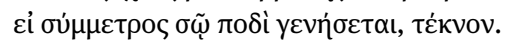

10 Eur. El. 520-546. 


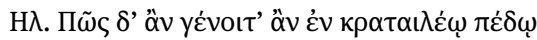

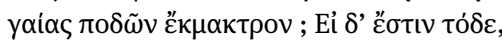

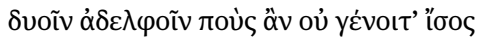

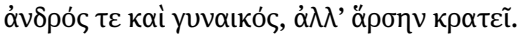

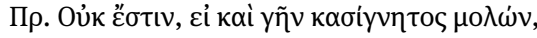
........

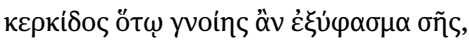

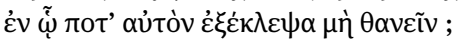

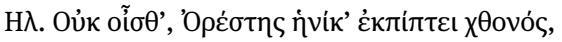

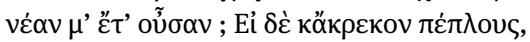

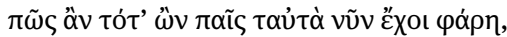

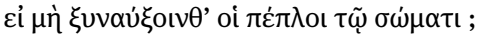
'A $\lambda \lambda^{\prime}$ ’

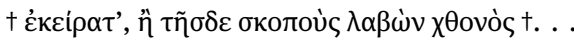

Old man. - Go look to see if the color of the cut lock is the same as yours, putting it to your own hair; it is usual for those who have the same paternal blood to have a close resemblance in many features.

Electra. - Old man, your words are unworthy of a wise man, if you think my own brave brother would come to this land secretly for fear of Aegisthus. Then, how will a lock of hair correspond, the one made to grow in the wrestling schools of a well-bred man, the other, a woman's lock, by combing? No, it is impossible. But you could find in many people hair very similar, although they are not of the same blood, old man.

Old man. - Then stand in the footprint and see if the tread of the boot will measure with your own foot, child.

Electra. - How could there be an imprint of feet on a stony plot of ground? And if there is, the foot of brother and sister would not be the same in size, for the male conquers.

Old man. - There is not, even if your brother, coming to this land . . by which you might know your loom's weaving, in which I once stole him away from death?

Electra. - Don't you know that I was still young when Orestes was driven out of the land? And even if I had woven him a robe, how could he, a child then, have the same one now, unless his clothes grew together with his body? But either a stranger, taking pity on his grave... ${ }^{11}$

Indeed, we observe in this dialogue a repetitive structure: every time the old man assumes that an element could be a token of Orestes, he invites Electra to make the comparison, for example, with her hair or her foot. In the first part of

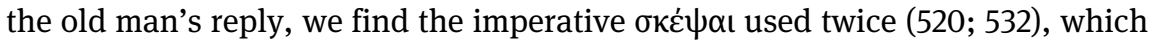
shows that the old man is drawing attention to the recognition process based on visual perception. This observation aims to verify the supposition articulated by the servant (introduced by ci in the Greek text). This supposition is based on the assumption of a physical similarity between brother and sister, represented

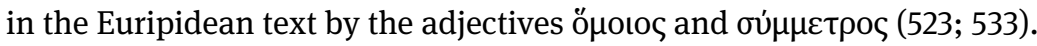

11 Translation by Edward P. Coleridge; see Oates/O’Neill (1938). 
For her part, the girl follows the same process in her replies: while formulating hypotheses to support the idea of the old man, perhaps thanks to a hypothetical optative system, she questions and then invalidates the very possibility of such a similarity between herself and her brother. The repetition of the interrogative $\pi \tilde{\omega} \varsigma(527 ; 534 ; 543)$ in Electra's lines underscores her interrogation of the method of supporting such hypotheses. In fact, Euripidean characters do not claim outright that any particular situation is impossible; instead, their interrogative sentences highlight practical impossibility. As such, it seems to me that we must neither neglect the type of sentence chosen by the playwright nor restrict it to a form of rhetorical process. In fact, it is my belief that the interrogative mode conveys a particular meaning which is addressed both to character and to the audience.

We find the same conceptual structure informing the third token (the woven garment) even though it is not visible onstage and is entirely conceived by the old man. What appears here is that the Euripidean scene does not revolve so much around the likelihood of a particular token, but rather around the search by the characters themselves as the means of effecting such recognition. This scene evokes the tools proper to the theatre to represent such an awareness. Specifically, Electra's questioning of the evidence of Orestes' identity highlights both the exploitation of the scenery and the space occupied by the actors (by the mention of the footprint on the ground, 534-535), the costumes (with the comparison between the size of the feet and especially between the hair, 520-521, and therefore the masks, of the two characters), and the theatrical prop that can represent a woven garment (539). In this sense, this scene of Electra is a way for Euripides to say that the method followed by Aeschylus to actuate recognition is not fully effective from a scenic point of view. One potential proof is the use of the term $\dot{\alpha} \mu$ ń $\chi \alpha v o \varsigma$ in Euripides' scene (529): if we refer to the various meanings listed in the $L S J,{ }^{12}$ this adjective is not, strictly speaking, a synonym for $\alpha \delta$ v́vatos (which means 'impossible'), but it emphasizes the lack of resources or means available for summoning in order to effect a process. Further encouragement for attributing a strong definition to this adjective is that it is built on the association of the privative prefix with the technical and theatrical term of $\mu \eta \chi \alpha v \eta$. Therefore, we have in it evidence that supports the idea that Euripides was interested in the exploitation and practical implementation of the topical rec-

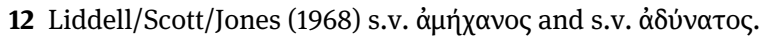


ognition scene. Thus, the above scene from Electra should be considered less a parody ${ }^{13}$ of the Libation Bearers than a reflection on the theatre and its tools for representing such a scene - thus, it has a metatheatrical reach.

In a related vein, I would next like to demonstrate that, in addition to his taking over the topos of recognition, Euripides also managed to reveal the structure and conventions of that scene through the representation of recognitions that fail to take place. While this may seem paradoxical, it is clear to me that by showing the causes of the failure of recognition (or difficulties presented by such scenes) in another author's work, the playwright exacerbated the purely artificial nature of the codes that govern this topos in the theatre. Furthermore, he even managed to renew them. The false recognition scene between Ion and Xouthos at the beginning of the eponymous tragedy bears witness to this idea. ${ }^{14}$

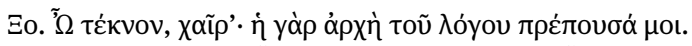

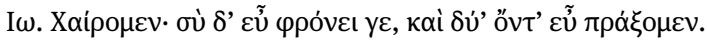

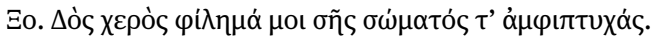

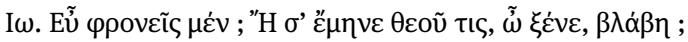

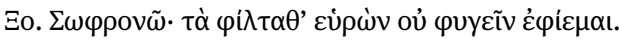

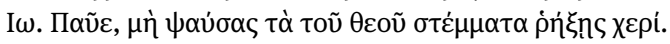

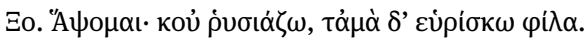

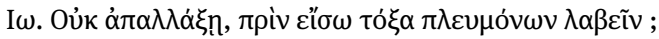

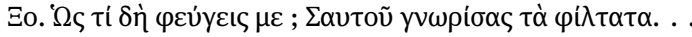

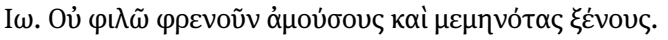

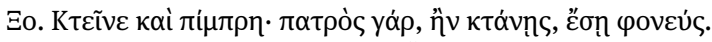

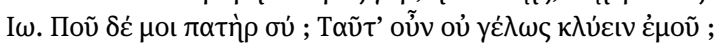

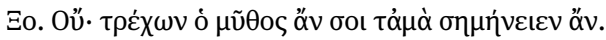

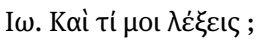

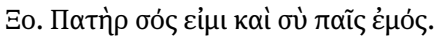

Xouthos. - My boy, welcome! That is a suitable way to begin speaking!

Ion. - I am well; as long as you stay in your right mind, we are both doing well.

Xouthos. - Let me kiss your hand, and throw my arms around your body!

Ion. - Are you in your right mind, stranger? Or has some damage from a god driven you mad?

Xouthos. - I am sane; since I have found my dearest, I long for him not to escape.

Ion. - Stop, do not break by your touch the garlands of the god.

Xouthos. - I will touch; I am not seizing you as a pledge, but I have found my own.

Ion. - Won't you stop, before you get an arrow in your side?

Xouthos. - Why do you try to escape from me? When you have met your own dearest. . .

Ion. - I do not like to teach rude and maddened strangers.

13 See commentaries of the scene, e.g., Bond (1974); Ronnet (1975) and those quoted in note 5. 14 Eur. Ion 516-530. 
Xouthos. - Kill me and raise my funeral pyre; but if you kill me, you will be the murderer of your father.

Ion. - How are you my father? Isn't this a joke on me?

Xouthos. - No; the story as it goes on will make clear my words to you.

Ion. - And what will you tell me?

Xouthos. - I am your father, and you are my child. ${ }^{15}$

We become aware in this passage of a kind of reversal of the topical recognition scene. In particular, there is an inversion of the traditional stages allowing for the reunion of two characters. Upon seeing Ion, Xouthos immediately addresses him as a father would his son; but this step is not effective, since it is not known why he, whom Ion regards as a stranger, behaves with such familiarity towards him.

We observe in this passage a very clear opposition between the two characters. On the one hand, we see in Xouthos's words many marks of tenderness

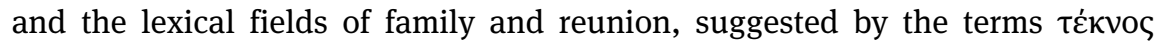

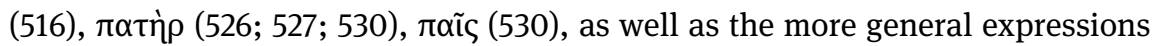

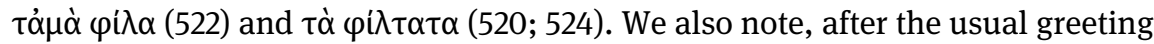
with $\chi \alpha$ ĩpe $(516 ; 517)$, the joint references to the process of recognition and ges-

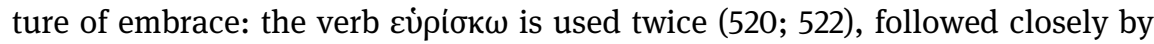
the verb $y v \omega \rho i \zeta \omega$ (524). In sum, we see in Xouthos's replies that it is normal for reunion with a dear one to be celebrated with an embrace. ${ }^{16}$ On the other hand, verse 518 highlights the bodily dimension of the reunion in the embrace with the verb $\alpha \mu \varphi ı \tau \tau u ̛\left(\omega\right.$, as well as with the mention of the enclosed body. ${ }^{17}$ This also tells us that there must be a specific gesture from the actors in this scene, which is confirmed by the exclamation of Ion in 521. Indeed, the fact that Xouthos is so violently rejected suggests that his wishes to embrace the one he thinks is his son are not merely a request but a physical action: the first actor must have gotten close to the second, which results in Ion's strong rejection. This double movement of approach and rejection alone symbolizes, both in words and in the

15 All translations of Euripides' Ion are by Robert Potter; see Oates/O’Neill (1938).

16 This then implicitly indicates to us that the embrace should be an integral part of the representation of the topical recognition.

I adopt, rather, a dramaturgical interpretation which allows me to comment on the scene according to the reception of the performance by the audience. I deliberately leave aside the many comments of critics that see in this passage a comic scene mobilizing the imaginary of pederasty. See for example Knox (1979) 250-274 and Lloyd (1986) 37. On theatrical gesture, see Capponi's chapter in this volume.

17 The very interesting structure of this verse is also notable as it is constructed in the image

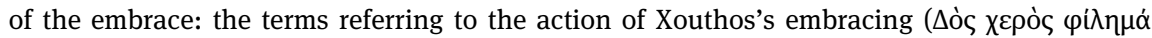

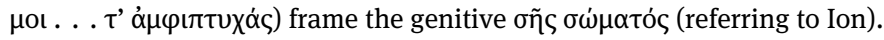


gestures and movements of the actors onstage, the very clear opposition of the two characters. Both act according to their own reasoning, and Xouthos' comments do not allow for either the dialogue alone to be effective or for Ion to better react to the situation.

We should note the use of the term $\xi \dot{\varepsilon} v o{ }^{18}{ }^{18}$ repeated in 519 and 525 by Ion, opposing the lexical field of the family employed by Xouthos. The fracture between the two characters is finally emphasized in this dialogue by Ion's proclamations of expressions conveying the meaning of madness (particularly 519 and 525).

I will now take this opportunity to comment in more detail on the metatheatrical remark in $527 .{ }^{19}$ Its interrogative nature and negative turn emphasize Ion's astonishment (or exasperation) in the face of the news of which Xouthos has just told him; however, they can also echo the astonishment (or perplexity) of the audience, as they have just been confronted with this ineffective scene. One potential reinforcement of this interpretation is the joint mention of a hearing verb, $k \lambda$ úcıv, which refers to the aural sense convened at the reception of the performance, and the adverb yé $\lambda \omega \varsigma$, which evokes laughter. Interpreting this verse as a wink of the playwright to his audience would imply here Euripides' anticipation of the public's reaction. However, such anticipation would not work without the poet's certainty of thwarting the expectations of the public and thus overturning the codes of representation of the recognition by making it fail at first.

What also supports this hypothesis is the essential role that this proposal occupies in the scene. Indeed, the line operates as a hinge between the two stages of recognition: before, the two characters speak but do not understand each other. Afterwards, however, Xouthos' statement is explanatory and picks up the various elements that led him to recognize Ion as his son from a chronological point of view. This is manifested by the last verses of the passage quoted above which announce the story (ó $\mu \tilde{\theta} \theta$ os) of Apollo's oracle and its role of clarification as to the present situation, notably by the use of the verb on $\mu \alpha$ iv $\omega$ (528). The metatheatrical remark in 530 has as such a dual function: it obviously represents an anticipation of the story to come, but it also operates a form of conclusion to the scene in question. Indeed, we see throughout the dialogue

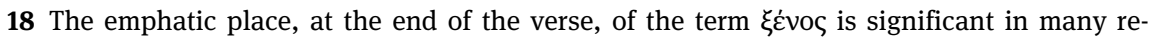
spects here. First, it serves to complete the verse, representing the state of mind of Ion regarding his interlocutor. But more importantly, it highlights the structure of the verse that begins with ov $\varphi \iota \lambda \tilde{\omega}$ : Ion's words insist on the inappropriateness of tenderness and affection discussed between two strangers.

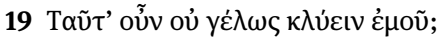


that the misunderstanding between the two characters is reflected in the inadequacy between the terms of the family and the personal pronouns of the second person in the mind of Ion. However, thanks to the intertwining of the marks of the first and second person in 530, Xouthos expresses more clearly than before the identity of each of them and the reciprocity of their relationship.

In this sense, we can see in these last verses of the quoted passage a point of reversal of the scene, where allusion to the feeling of the spectators occupies a more prominent place. After suggesting the surprising and confusing nature of the scene to the public, Euripides highlights transition to a new stage and reassures his audience of the upcoming success of the reunion. Therefore, we observe that this scene is helpful for understanding the poet's dramaturgical work on the staging of the recognition in the Ion: the conventions attributed to this topos are exacerbated by its failure (and more particularly, its scenic dimension, thanks to rejection of the embrace), and the two-step decomposition of recognition is underlined by the key role given to the metatheatrical remark in 527, which implies the incongruity of the scene.

Next follows the story of the oracle of Apollo, who designated Ion as the son of Xouthos, a narrative which finally is able, in a rather artificial way, to operate as the recognition. ${ }^{20}$

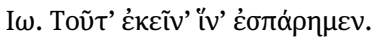

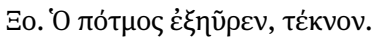

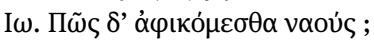

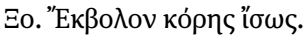

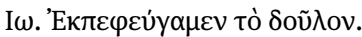

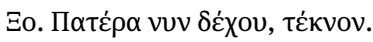

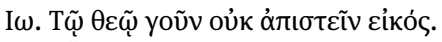

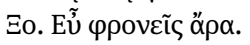

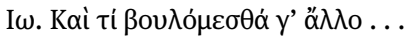

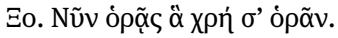

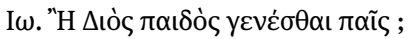

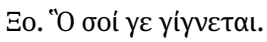

$\mathrm{I} \omega$. 'H $\theta \dot{i} y \omega \delta \tilde{n} \theta$ ' oĭ $\mu$ ' है $\varphi v \sigma \alpha \nu$;

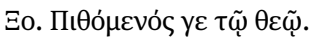

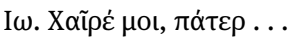

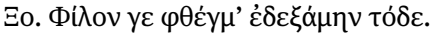

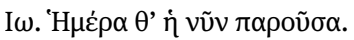

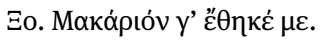

20 Eur. Ion 554-562. 
Ion. - It was then that I was conceived.

Xouthos. - Fate has discovered you, my son.

Ion. - How did I come to the temple, then?

Xouthos. - Perhaps you were exposed by the girl.

Ion. - I have escaped from slavery.

Xouthos. - Now receive your father.

Ion. - It is reasonable not to distrust the god, at any rate.

Xouthos. - Now you are in your right mind.

Ion. - And what else do I want?

Xouthos. - Now you are seeing what you ought to see.

Ion. - Than to be the son of Zeus' son?

Xouthos. - Which is yours.

Ion. - Am I really touching the one who gave me birth?

Xouthos. - If you trust in the god.

Ion. - Welcome, father!

Xouthos. - What a sweet word to hear!

Ion. - This present day. . .

Xouthos. - Has made me happy.

This is emphatically underlined by Euripides, who uses $1^{\text {st }}$ and $2^{\text {nd }}$ personal pronouns, as well as the lexical field of vision combined with that of reason. Thus, we observe that this was a good opportunity for Euripides to stage the artificiality of the process of recognition and its implementation stage.

Shifting to another of Euripides' tragedies, I will next highlight how the same general theme is present in Helen. Indeed, even though the play is very different, the recognition scene between Helen and Menelaos also illustrates that the challenge of such a moment for the playwright is to resolve the dichotomy between their vision and the alleged knowledge that they associate with it. In fact, the first confrontation between Helen and Menelaos leads to a failure, an aporia, since Menelaos cannot bring himself to admit that his real wife is in front of him when he thinks he has left her at the bottom of a cave near the shore. ${ }^{21}$

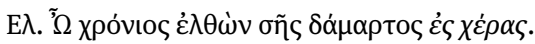

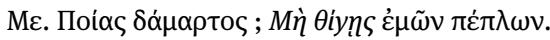

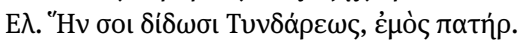

Mع. '̊

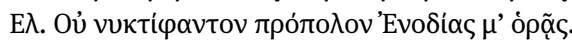

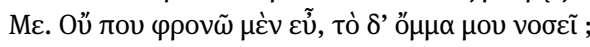

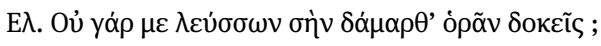

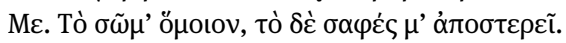

21 Eur. Hel. 566-592. I quote here the text established by Kannicht. See Kannicht (1969) 161-162. 


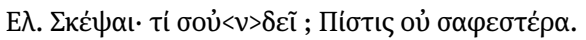

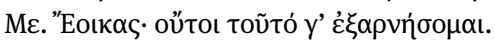

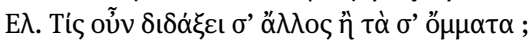

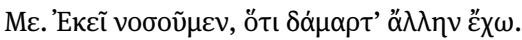

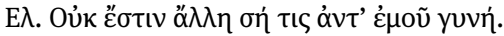

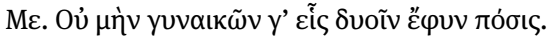

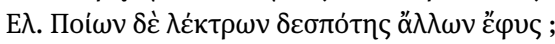

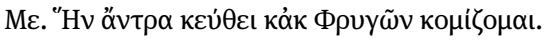

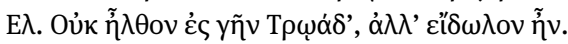

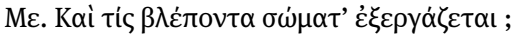

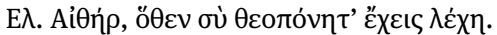

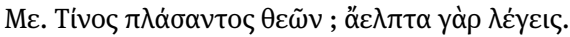

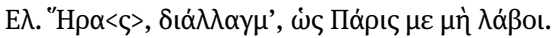

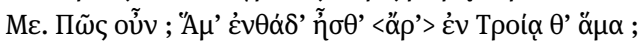

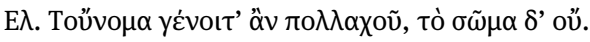

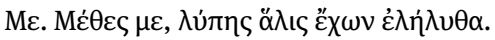

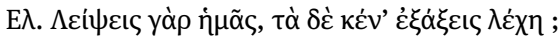

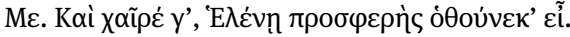

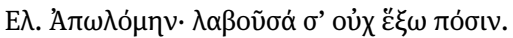

Helen. - Oh, at last you have come to the arms of your wife! Menelaos. - What do you mean by wife? Do not touch my robe.

Helen. - The one whom Tyndareus, my father, gave to you.

Menelaos. - $\mathrm{O}$ torch-bearing Hekate, send visions that are favorable!

Helen. - You see in me no specter of the night, attendant on the queen of phantoms.

Menelaos. - Can it be that I am in my right mind, but my sight is failing?

Helen. - Don't you think that when you look at me you see your wife?

Menelaos. - Your body resembles hers, but the real truth robs me of this belief.

Helen. - Look; what more do you need? Who knows better than you?

Menelaos. - You are like her; I will not deny that at least.

Helen. - Who then shall teach you, if not your own eyes?

Menelaos. - It is there that I am ailing, because I have another wife.

Helen. - You have no other wife but me.

Menelaos. - As one man, I am certainly not the husband of two women.

Helen. - You are the master of what other wife?

Menelaos. - The one hidden in the cave, whom I am bringing from Troy.

Helen. - I did not go to Troy; that was a phantom.

Menelaos. - And who fashions living bodies?

Helen. - The air, out of which you have a wife that the gods labored over. Menelaos. - What god's handiwork? You are saying things beyond hope.

Helen. - Hera's, as a substitute, so that Paris would not have me.

Menelaos. - How then could you be here and in Troy at the same time?

Helen. - The name may be in many places, though not the body.

Menelaos. - Let me go! I have come here with enough pain. 
Helen. - Will you leave me, and take that phantom bride away?

Menelaos. - Yes, and fare well, for your likeness to Helen.

Helen. - I am ruined! I found you, my husband, but I will not have you. ${ }^{22}$

It is important here to notice the distinction (consciously performed by Menelaos) between the name of Helen or circumlocutions that designate her, and Menelaos' use of the $2^{\text {nd }}$ person pronoun. Such a move clearly shows that he does not identify the woman in front of him as his wife. Above all, this scene allows us to see two very different types of reasoning: Menelaos relies entirely on history as he knows and experiences it $(575 ; 577 ; 581 ; 571 ; 573)$, while Helen advocates for sensation and perception (especially vision) as the only source of reliable knowledge, as shown for example in line 580 (576; 578).

Through these examples, we observe that Euripides not only criticized a conventional model of the recognition scene, but he also clearly demonstrated, even within his own tragedies, the difficulties of its staging.

\section{Metatheatre as a Tool for Renewing the Recognition Scene's Staging}

In this section, I aim to demonstrate how Euripides invented new dramaturgical tools for the staging of recognition scenes. In order to show how Euripides undertook the task of re-motivating the processes that inspire recognition, I will highlight one example of each of his tools.

For my first example, I would like to return to the case of Ion. ${ }^{23}$ I believe this example will allow me to effectively demonstrate how Euripides used dramatic composition to justify a seemingly artificial scene. ${ }^{24}$

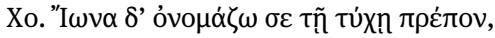

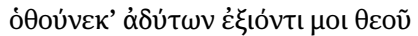
ı’

Xouthos. - Ion I name you, as befits your fortune, since you were the first to meet me as I came out of the god's shrine.

22 All translations of Euripides' Helen are by Edward P. Coleridge; see Oates/O'Neill (1938). However, the reader will note that we swapped some verses in Coleridge's translation in order to match the Greek text quoted and established by Kannicht.

23 Eur. Ion 661-663.

24 On this scene, see Giannopoulou (2000). 
Previously, I showcased how Euripides emphasized the artificiality of recognition between Xouthos and Ion. But by using the etiological aim of the play, he also re-motivated this recognition scene within the economy of the play. Indeed, the very fact of justifying the name of the hero by a pun in Greek draws the attention of the public to the arrangement of the tragedy: Ion is named as such by Xouthos because he is the first one that Xouthos meets at the exit of Apollo's temple. However, it is Euripides who designed his play so that Ion is the first contact of Xouthos. Thus, this false recognition scene allowed Euripides to justify not only the name of the hero, but also to re-motivate a complex dramatic structure. That the recognition scene could seem at first incongruous, or even comical, is justified afterwards. Moreover, it seems to me that the pleasure experienced at this point by the spectators is not only due to the quick succession of opposing tones but also results from the opportunity offered by the playwright to perceive poetic and theatrical workings. Indeed, audience members are not only aware of the artificiality of theatrical conventions or the need to follow a certain logic allowing recognition to happen; they are also able to change their judgment upon the stage and to recognize the playwright's skill.

Moving now to another tool used by Euripides to provoke recognition - the props $^{25}$ - I move to explain another example in the same tragedy, but this time during the real recognition between Ion and his mother Creusa.

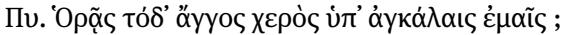

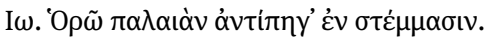

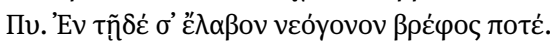

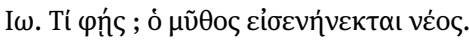

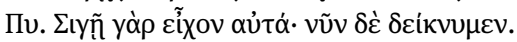

Priestess. - Do you see this vessel in my arms?

Ion. - I see an ancient cradle, in garlands.

Priestess. - In this I received you when you were a new-born infant.

Ion. - What are you saying? A new story is introduced.

Priestess. - I kept it in silence; now I reveal it.

In this dialogue between Ion and Pythia, there are many noteworthy references to the scenic situation; the verbs of visions (1338; 1339), deictics (1338; 1340; $1349 ; 1352)$ or temporal references to the present of the enunciation (1342; 1349; 1355) bear witness to this. Recalling the funeral urn used by Sophocles in his Electra, it is readily apparent that the use of props by Euripides was here very

25 Eur. Ion 1338-1341 and 1348-1355. 
different. Indeed, the urn is used in Sophocles as the stage incarnation of a false rumour, a $\mu \tilde{v} \theta$ os. In other words, it was a tool to spread news of the death of Orestes. On the contrary, here in Euripides' work, it is used as an object in that it represents a concrete way to bring about the reunion.

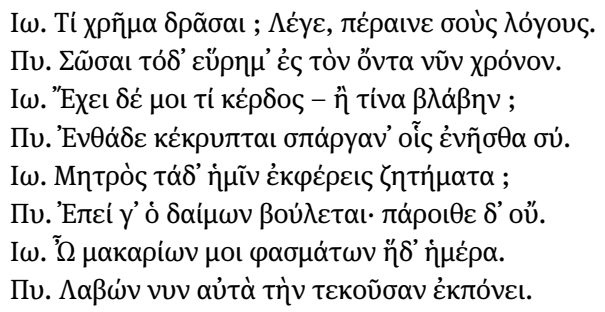

Ion. - To do what? Speak, finish what you have to say.

Priestess. - To keep to this time what I found.

Ion. - What gain does this have for me, or what harm?

Priestess. - The baby-clothes in which you were wrapped are hidden here.

Ion. - You are producing a means to find my mother?

Priestess. - Since the god wishes it; before, he did not.

Ion. - O day of blessed discoveries!

Priestess. - Now take them and find your mother.

Having discussed the use of props by Euripides, I now focus on another method used by Euripides to renew the staging of recognition: the use of an intermediate character. Even if it had been done before, for instance by Sophocles in Oedipus Rex, Euripides uses this pattern in a different way. One example of this comes from the Electra, ${ }^{26}$ in which Euripides makes the old man the necessary intermediary of the reunion between Electra and Orestes. Another example is the scene in Helen where the messenger also acts as a trigger for the recognition. ${ }^{27}$

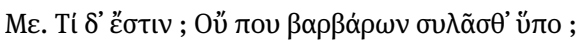

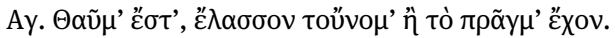

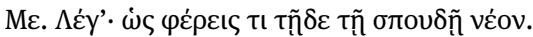

Menelaos. - What is it? Surely you are not being plundered by the foreigners?

Messenger. - It is a miracle; what I say is of less account than what happened.

Menelaos. - Tell me; for, judging by this eagerness, you are certainly bringing something new.

26 Eur. El. 509-581.

27 Eur. Hel. 600-602; 616 and 622-623. 
Indeed, it is only possible for the reunion to occur after the intervention of the companion of Menelaos and, importantly, his account of the disappearance of Helen's ghost. The use of the term $\theta \alpha \tilde{u} \mu \alpha$ (601) or the adjective véos (602) reveals the astonishment of the messenger.

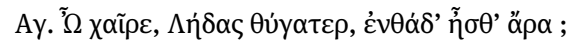

Messenger. - Welcome, daughter of Leda, were you here after all?

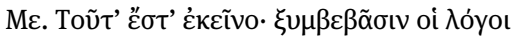

oi $\tau \tilde{\eta} \sigma \delta ’ ' \dot{\alpha} \lambda \eta \theta \varepsilon \tilde{c} \varsigma$. [. . .].

Menelaos. - This is the meaning of that; her words have turned out to be true; [. . .].

But a few verses further, the simplicity with which he calls Helen (616) echoes the passage that precedes and affirms the association of knowledge with the sense of vision. Although this is exactly what Menelaos was unable to do before, the messenger accomplishes it onstage in a straightforward manner in line 601 . What is particularly interesting in this verse is the superiority that the messenger attributes to the action rather than to Helen's name or to the story of the famous myth. It seems then that this line echoes willingly Euripides' purpose in this tragedy, which is a re-motivation of a well-known story through a new version of the myth. In order to support such an interpretation and to give a metatheatrical meaning to this reply, it is my opinion that the messenger is very clearly used as a dramaturgical tool allowing the progression of the plot and the recognition's achievement. To this point, witness lines 622-623, which embody Menelaos' understanding of the situation onstage.

The recognition scene between Helen and Menelaos can now take place, thanks to the recourse of the amoebaean song and its choreography with which Euripides motivated this long episode. ${ }^{28}$ Indeed, by breaking down the recognition scene into two stages, interspersed with the salutary intervention of the messenger, Euripides managed to give a skilful display of the different stages of recognition, passing from doubt to certainty of the characters' identity, then to the emotion of the meeting, and finally to the embrace. And this cognitive level is intertwined with a theatrical one, because using amoebaean singing and choreography allowed Euripides to re-motivate the traditional vocabulary of recognition.

28 Eur. Hel. 622-638 and 648-659. See Cerbo (1989) and Willink (1989). 


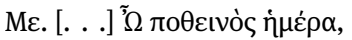

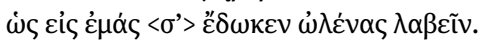

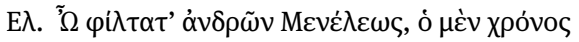

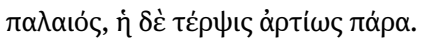

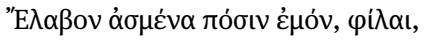

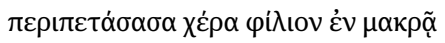

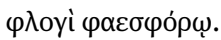

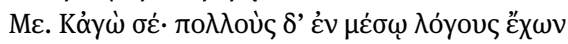

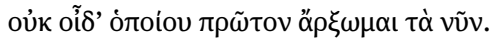

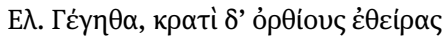

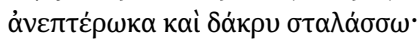

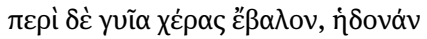

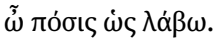

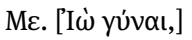

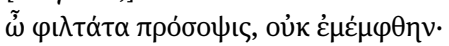

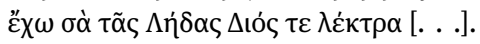

Menelaos. - [. . .] O longed-for day, that has given you to my arms!

Helen. - O Menelaos, dearest of men, the time was long, but delight is just now ours. With joy I have found my husband, friends, I have embraced my dear one, after long days of blazing light.

Menelaos. - And I have found you; but I have many questions about those years; now I do not know what to begin with first.

Helen. - I am so happy, the hair rises on my head and my tears run down. I fling my arms around your neck, [635] dear husband, to have my delight.

Menelaos. - O dearest sight! I have no fault to find: I have my wife, the daughter of Zeus and Leda [. . . ].

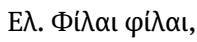

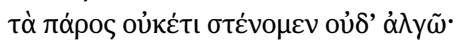

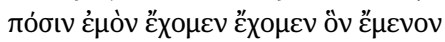

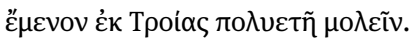

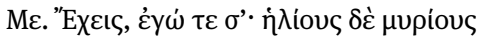

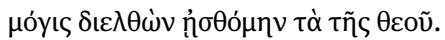

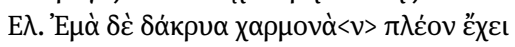

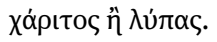

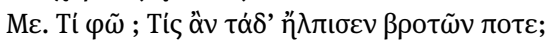

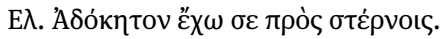

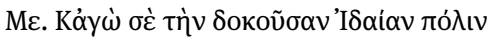

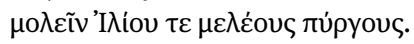

Helen. - My dear friends, I no longer sigh or grieve over what is past. I have my husband, for whom I have been waiting to come from Troy for many years.

Menelaos. - You have me, and I have you; although it was hard to live through so many days, I now understand the actions of the goddess. My joy is tearful; it has more delight than sorrow. 
Helen. - What can I say? What mortal could ever have hoped for this? I hold you to my heart, little as I ever thought to.

Menelaos. - And I hold you, whom we thought to have gone to Ida's city and the unhappy towers of Ilion.

The metatheatre is particularly present at the end of the scene, especially in the use of the vocabulary of the embrace associated with singing. In fact, the viewer can only be sympathetic to the visual rendering of this scene that still manages to bring together two lovers separated for so many years. If we examine the pas-

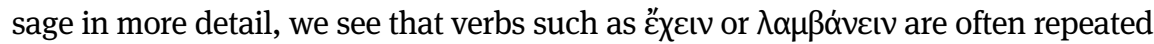
by characters, like a refrain that punctuates the song of the reunited spouses (624; $627 ; 630 ; 635 ; 638 ; 650 ; 652 ; 654 ; 657)$. But it would be rather poor from a scenic point of view to imagine that these words are only an incarnation of the reunion. Thus, we might also imagine that there existed choreography corresponding to the song and performed by Helen and Menelaos. ${ }^{29}$ To this refrain, then, we can suppose a corresponding repetitive gesture within the dance of the actors emphasizing the physical rapprochement of the two characters during this reunion. Thus, words support acting. By virtue of its composition and the appropriate use of song and dance, Euripides consequently managed to create a powerful scene, both visually and musically, that reignited the traditional vocabulary of recognition.

\section{Metatheatre as a Tool for Promoting a New Dramaturgical Type}

In my third and final section, I will expand upon my examination of Euripides' metatheatrical remarks to show that their sole purpose was not simply to allow Euripides to make the audience attentive to the questioning or the reinvention of the codes structuring the recognition and its representation. Indeed, further examination of the vocabulary employed and the attempts to reconstitute the

\footnotetext{
29 As far as we are concerned, we think that it would be more meaningful to imagine the actors choreographically performing the gestures and the reunion they evoke repeatedly in their words. If the metre assures us about the lyrical nature of the passage, it is the properties and specificities of the theatrical performance which might suggest the need for a visual embodi-

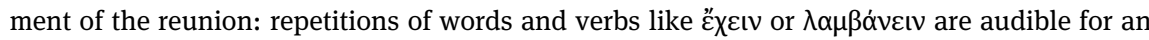
attentive and educated audience, but would be clearer for a large public, even distracted or kept away from the stage.
} 
staging of this reunion encourage us to consider these metatheatrical remarks as a kind of manifesto in action, advocating an aesthetics of the surprise and the spectacular.

First, I would like to mention the very frequent use by Euripides of terms highlighting the incredible and unexpected dimension of the events represented and

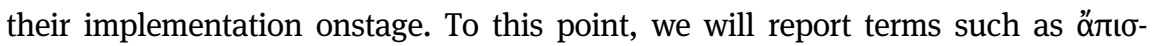

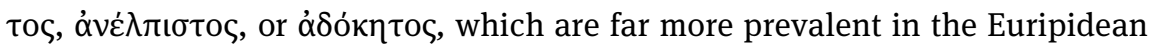
corpus relative to their use by Aeschylus or Sophocles. ${ }^{30}$ Similarly, the terms of the $\theta \alpha \tilde{v} \mu \alpha$ family are overrepresented by Euripides, highlighting association with the visual dimension of the tragic event. ${ }^{31}$

Furthermore, some Euripidean plays show the poet as the craftsman of an extraordinary plot full of twists. For example, Helen's last verses emphasize the role of the poet in the dramatic construction of the tragedy and his desire to promote sudden changes of circumstance. ${ }^{32}$

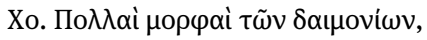

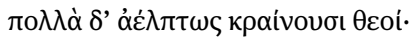

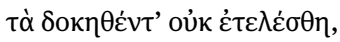

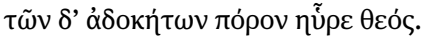

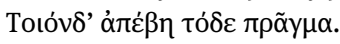

Chorus. - Many are the forms of divinities, and many things the gods bring to pass unhoped for. And what was expected has not been fulfilled; for what was not expected, a god finds a way. Such was the result of this action.

3015 occurrences of árıбтоৎ in Euripides: Ion 751; 1608; Hel. 1148; 1520; Hec. 689; Suppl. 479; El. 350; HF 1017. See note 38 for occurrences in IT. In comparison, only 2 occurrences in Sophocles: Ajax 683 and Phil. 868, and 6 occurrences in Aeschylus: Suppl. 277; Prom. 832; Sept. 842;

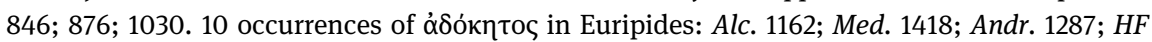
92; Ion 1448; IT 896; Hel. 657; 1691; Phoen. 311; Bacch. 1391. In comparison, only 1 occurrence

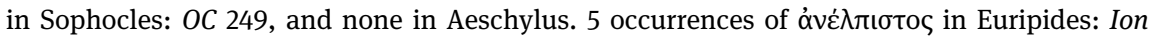
1395; El. 570; IT 1495; Hel. 412; 1143. In comparison, only 2 occurrences in Sophocles: Trach. 673; El. 186 and 1 occurrence in Aeschylus: Suppl. 330.

31 As an example, 23 occurrences of $\theta \alpha \tilde{u} \mu \alpha$ in Euripides, 10 in Sophocles and 2 in Aeschylus.

32 Eur. Hel. 1688-1692. Many Euripidean plays end with similar verses; see for instance: Alc. 1159-1163; Andr. 1284-1288; Bacch. 1388-1392; see also the use of slightly different verses in Med. 1415-1419. 
The use of the term $\theta \varepsilon$ ó $\varsigma$ in the singular (1691) after plural uses $(1688 ; 1689)$ in the preceding lines also shows us that Euripides amused himself by emphasizing the essential role of the poet as architect of the plot and master of the destiny of his characters. ${ }^{33}$

Moreover, we can say that the dramatic composition plays a preponderant role in the new aesthetics advocated by Euripides. The Ion illustrates this well, since we can observe that the composition of this tragedy is very elaborate and is constructed with a mirrored structure. In other words, each scene is either duplicated or put in opposition to another. This is the case with the recognition: the real recognition appears in the exodos and serves as a response to the false recognition between Xouthos and Ion in the second episode. This means that the composition of the work itself encourages the viewer to remember and compare the two scenes. From then on, the understanding and interpretation of the tragedy, even unconsciously, takes place in view of the significance produced by the confrontation of these scenes and their visual and aural properties. It should be noted that the term $\mu \varepsilon \tau \alpha \beta o \lambda \eta$, particularly used later by Aristotle to talk about reversals induced by events and recognitions, appears only in the Euripidean corpus. ${ }^{34}$ At the end of the play, for example, Ion associates with Fate the participle of the verb $\mu \varepsilon \tau \alpha \beta \alpha \lambda \lambda \lambda \omega .{ }^{35}$ His metatheatrical comment shows within the play that its plot is surprising and full of unpredictable twists.

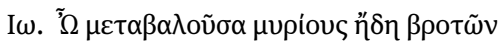

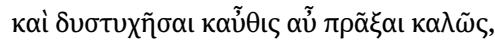

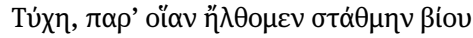

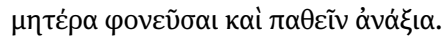

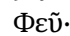

33 The idea of proximity between the poet and the divinity, especially Apollo, is recurrent in Greek poetry, for example in the Presocratics or Pindar. See for example Pindar's Olymp. 3.6-7; 11.8-9; Nem. 4.42.

Maybe this passage is also an allusion to the subject of Plato's Ion, in which the philosopher discusses lyric inspiration and the art of the craftsman: Euripides might suggest, against Plato, that poetry is not just about divine inspiration, but altogether a gift from the god and a $\tau \varepsilon \dot{x} \vee \eta$ improved by the author.

Later, the proximity between the poet as a lyric creator and the divinity appears for examples in Callimachus' Hymns.

348 occurrences of $\mu \varepsilon \tau \alpha \beta$ o $\lambda$ n in Euripides' complete plays and 6 in the fragments. See HF 735; 1292; Tro. 615; Or. 234; IT 722; Bacch. 1266; IA 500; 1101. In comparison, 2 occurrences in contexts of citing Aeschylus' fragments apud Plut. De E apud Delphos 9.389a; Demetr. 35.4, and none in the Sophoclean corpus.

35 Eur. Ion 1512-1519. 


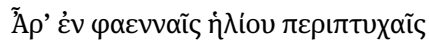

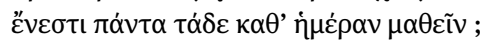

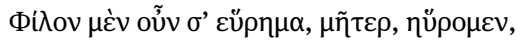

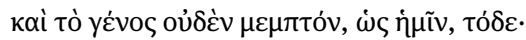

Ion. - O Fortune, you that have already changed the lives of countless mortals, involving them in ills, and raising them to happiness again, to what a point of life had I come, ready to kill my mother and suffer unworthily. Ah! Is it possible to learn all this day by day, in the sun's bright encircling rays? I have made a dear find in you, mother; nor do I see anything to blame in my birth.

The reversal of the final situation allowed by the interventions of the Pythia and Athena (i.e. the recognition) is made significant explicitly by the playwright through a specific metatheatrical remark. But I will even go so far as to say that the very structure of the play and the mention of the recognition's vocabulary also alert us to the possibility that it is thematized within the dramatic structure itself.

As a final example, I will examine the recognition scene of Iphigenia in Tauris. Indeed, the metatheatrical remarks that punctuate the scene show that the goal of Euripides in this passage was to create a new visual tableau. ${ }^{36}$ The poet underlined the unexpected and prodigious mood of the reunion through his unprecedented staging.

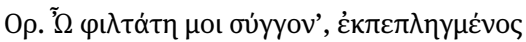

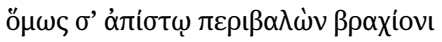

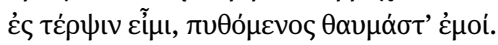

Orestes. - My dearest sister, with what astonishment and delight I hold you in my unbelieving arms, after learning these marvels! ${ }^{37}$

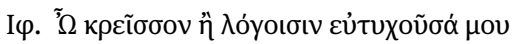

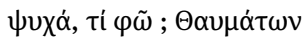

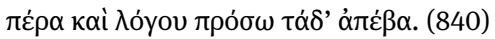

Iphigenia. - O my soul, you have been more fortunate than words can say. I have come upon things that are beyond wonder, far from speech.

In support of my hypothesis, I will highlight the seven occurrences of the adjective ö́rıтоৎ in this tragedy alone. ${ }^{38}$ Indeed, after Iphigenia's doubt and surprise, and after Orestes' proof of identity, the playwright chose not to interrupt the

36 Eur. IT 795-797 and 837-840.

37 All translations of Euripides' Iphigenia in Tauris are by Robert Potter; see Oates/O’Neill (1938).

38 IT 328; 388; 782; 796; 1293; 1298; 1476. 
reunion, but rather to extend it. The public then attends a kind of pause in dramatic time created by Iphigenia's monody; it breaks the course of the action in an attempt to restore the chronology between the past events Iphigenia knows of and the incredible present situation in which she finds herself. By this dramaturgical process of decomposing the recognition into several steps, and by having recourse to the monody, Euripides not only stages the cognitive difficulty in achieving the recognition, but he also underlines the power of singing over the partial ineffectiveness of speech. Now, once again, it must be emphasized that if there was a song performed on the Athenian theatre's stage, a choreography would have completed it. And via two metatheatrical remarks made by the coryphaeus and then by Pylades, Euripides emphasizes the extraordinary and unprecedented properties of the scene that just unfolded. ${ }^{39}$

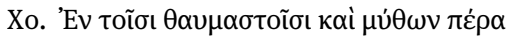

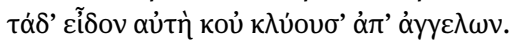

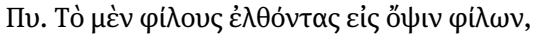

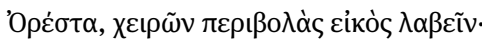

Chorus Leader. - It is marvelous and surpasses a fable, this event that I myself have seen and shall relate, not as hearsay.

Pylades. - When friends come into the sight of friends, Orestes, it is reasonable to embrace.

My suggestion is to view in the conclusion of the chorus support for an unprecedented show, or better yet, an unprecedented tableau. First, the performance of a song and its choreography, and second, the use of the dual ${ }^{40}$ at the end of Iphigenia's monody both suggest the prolongation of the pathetic effect with an embrace. To the agitation of the monody there corresponds a similarly moving silent and static scene. The theatricality of the stage is then accentuated by the words of the chorus and Pylades, a sort of echo to the astonishment or admiration of the stage by the spectators. But even more, and this is all the strength of the use of metatheatre in this scene, the words of the coryphaeus insist on the unspeakable nature of such a moment (900). However, to observe the ineffectiveness of speech in describing such an emotion only further emphasizes the power and efficacy of the constructed scene and its spectacle, that is to say, the visual tableau produced.

We have seen that Euripides made surprise and wonder an essential element of his dramaturgy, which he elaborated by commenting on it. Importantly, we

39 Eur. IT 900-903.

40 Eur. IT 898. 
have also seen that it is not wholly appropriate to consider these metatheatrical remarks as simple intra-scenic echoes to the feelings and astonishment of the public. These remarks reveal furthermore that Euripides utilized them in order to integrate his spectators into his process of reinvention of the recognition scene's traditional staging. In this way, the audience was better equipped to understand the different degrees of meaning of the representation and can better appreciate its effects.

\section{Conclusion}

Thus, this study of the four recognition tragedies shows that the repeated treatment of this pattern by Euripides in his final works is not redundant. It consists instead of dramaturgical experimentation emphasized by the many metatheatrical remarks punctuating the tragedies. The repetition of the topos must therefore be understood as a means for the playwright to question his theatrical practice and to innovate in the field. In addition, the examples discussed above have shown us that the metatheatre, as it is implemented in Euripidean tragedies, is not theoretical. It does not express itself in the reflexive mode and does not evoke the theatre and its properties in general. The tools for stage performance - such as props, costumes, visual and sound effects of a tableau, a monody or its choreography - are at the heart of Euripides' dramaturgy. The effect of these scenes and innovations on the audience is also highlighted by the author's use of the metatheatre. In this sense, it consists rather in a singular dramaturgical practice, elaborated in taking itself as an object.

However, we observe that Euripides did not use a single, unique metatheatrical tool in each tragedy to put his dramaturgical practice and innovation into perspective. In fact, the tragedies studied are very different, whether in their structure or in their treatments of recognition. Yet, even though they might have operated in varying degrees and modes, Euripides utilized in each of them the two levels of the theatrical work: the structural level, which gives meaning to the arrangement of the scenes in relation to each other; and the scenic level, which makes wholly meaningful visual and aural languages, for example by the use of singing and of the scenic tableau.

In addition, we have seen that the recurrent use of metatheatrical remarks consists of a kind of accompaniment of the spectators by the playwright, integrated in a subtle way into the economy of the play. Euripides made his audience more attentive to the strictly theatrical properties of his tragedies, which generated a more active and intense participation in the show on the part of the 
spectators. We are therefore very far from a reflexive or elitist conception of metatheatre, which would be addressed only to a small number of scholars particularly fond of drama. Euripides' metatheatrical approach allowed his audience to live the theatrical performance in all its richness and to adopt willingly a new type of dramaturgy, more focused on $\pi \dot{\alpha} \theta$ os and surprises - a type of dramaturgy which was, in a word, more spectacular. 